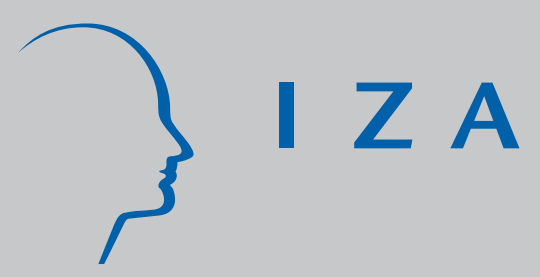

IZA DP No. 3897

A Note on Measures of Human Capital for Immigrants: Examining the American Community Survey and New Immigrant Survey

Randall Akee

Mutlu Yuksel

December 2008 


\title{
A Note on Measures of Human Capital for Immigrants: Examining the American Community Survey and New Immigrant Survey
}

\author{
Randall Akee
}

$I Z A$

Mutlu Yuksel

IZA

\section{Discussion Paper No. 3897 \\ December 2008}

IZA

P.O. Box 7240

53072 Bonn

Germany

Phone: +49-228-3894-0

Fax: +49-228-3894-180

E-mail: iza@iza.org

Any opinions expressed here are those of the author(s) and not those of IZA. Research published in this series may include views on policy, but the institute itself takes no institutional policy positions.

The Institute for the Study of Labor (IZA) in Bonn is a local and virtual international research center and a place of communication between science, politics and business. IZA is an independent nonprofit organization supported by Deutsche Post World Net. The center is associated with the University of Bonn and offers a stimulating research environment through its international network, workshops and conferences, data service, project support, research visits and doctoral program. IZA engages in (i) original and internationally competitive research in all fields of labor economics, (ii) development of policy concepts, and (iii) dissemination of research results and concepts to the interested public.

IZA Discussion Papers often represent preliminary work and are circulated to encourage discussion. Citation of such a paper should account for its provisional character. A revised version may be available directly from the author. 
IZA Discussion Paper No. 3897

December 2008

\section{ABSTRACT}

\section{A Note on Measures of Human Capital for Immigrants: Examining the American Community Survey and New Immigrant Survey ${ }^{*}$}

In this paper we examine whether where one acquires their human capital matters in earnings regressions. We focus on a nationally-representative US data set and find that there is little difference between a measure of total years of education and measures for US and foreign-based years of education. There is a large difference, however, in where total experience is acquired: US-based experience commands a higher return to wages and is statistically highly significant. The measures used in this analysis must be inferred based on the year of migration to the US. Using an immigrant-specific data set, the New Immigrant Survey which contains explicit information on the human capital acquired in the US and abroad, we confirm these results.

JEL Classification: $\quad$ I21, J24, J61

Keywords: immigrants, schooling, rates of return

Corresponding author:

Randall Akee

IZA

P.O. Box 7240

D-53072 Bonn

Germany

E-mail: akee@iza.org

\footnotetext{
*We are grateful to Barry Chiswick, Deborah Cobb-Clark, David Jaeger and Arthur Sweetman for their comments and suggestions on this project. Any errors, omissions, or oversights are our own.
} 


\section{Introduction}

Immigrants' human capital plays an important role in assimilation and labor market success in the host country. Given the heterogeneity in school systems and quality of education across countries, the transferability of foreign education and experience may differ according to country of origin. Decomposing immigrants' education and experience according to where it is acquired is very important in analyses of immigration assimilation and labor market success. However, identifying the contributions of different kinds of human capital on the success of immigrants such as home country education or experience is notoriously difficult due to a lack of accurate information on immigrant characteristics in the home country. Aggregating measures of education and experience may mask important differences and potential obstacles to immigrant success in the host country.

Typically, questions on nationally representative surveys treat immigrants similarly to native-born respondents in terms of educational attainment and do not explicitly inquire as to where the education or experience was acquired. For instance, previous researchers using US data have inferred the years of education acquired in the US and abroad using a categorical variable for year of migration contained in the US census data (Schoeni (1997), Bratsberg and Ragan (2002)). Unfortunately, prior to the 2000 US census the year of entry variable was only available in three and five year categories; the exact year of entry is now available in the 2000 US Census and the new annual American Community Surveys (ACS). Researchers focusing on other countries have exploited data sets that focus specifically on immigrants' home country characteristics and their respective labor market outcomes in the host country (e.g. Friedberg 
(2000) for Israel, Schaafsma and Sweetman (2001) for Canada, Hartog and Zorlu (2009) for Netherlands).

This article utilizes the exact year of migration in a nationally representative data set in order to understand whether aggregate human capital measures hide important differences in where education and experience was acquired. Given the newly available variable in the American Community Survey (ACS) since 2000, we are able to infer a more accurate measure of immigrant human capital and the location where it was acquired. Our findings indicate that there is very little difference across the aggregated measures of education; on the other hand, the origin of the experience variable matters tremendously in determining wages of immigrants.

Additionally, we explore another data set to investigate the return to education and experience of newly arrived immigrants in the US. We analyze the returns to education and experience for recent immigrants using the New Immigrant Survey (NIS) data which focuses on new legal immigrants to the US and provides a wealth of pre-migration information such as educational attainment, labor force experience and information on previous migration experience. It is possible to ascertain exactly the years of schooling received outside of the US in this data. We find the assumption that recent immigrants to the US have no US education is not always accurate. Our analysis indicates that almost five percent of the new legal immigrants (non-visa adjustees) to the US have some US education and this can substantially affect the estimated return to education. Additionally, we find profound differences in the rates of return for experience depending upon where it is acquired.

In the next section, we discuss the ACS data set in detail. The third section describes the creation of our education and experience variables. We calculate years of education and experience by making standard assumptions about the immigrants' human capital acquisition. In 
the fourth section, we discuss briefly how the New Immigrant Survey data set relates to our ACS findings. In section five, we conclude with a brief discussion of the relative advantages and disadvantages to the measures contained in these two data sets.

\section{American Community Survey Data}

In this paper, we first focus on the American Community Survey (ACS) which is a monthly sample of US households. The ACS sample design approximates the Census 2000 long form sample and it is intended to eventually replace it. Each month a sample is drawn to represent each U.S. County and the selected monthly sample is mailed the survey. The 2004 ACS is a 1-in-239 national random sample of the population; the sampling unit of the ACS is the household and it provides information on all persons residing in the household. In 2004, the sample consisted of 514,830 households and 1,194,354 person records.

We limited our 2004 ACS sample to working-aged immigrants who were currently employed and report positive wages or salary income (the self-employed were omitted from our analysis). We group state of residence and the country of origin variables into regional categories; this allows us to make comparisons with the New Immigrant Survey in section three. Our final sample consists of 55,879 observations.

In Table 1, we provide the descriptive statistics for our 2004 ACS data. The mean of log annual earnings is 10.09 , and average income is $\$ 37,600$ for all immigrants in our sample or $\$ 31,600$ for non US citizen immigrants. In this sample the average age is 39.5 years old. The total years of education is 13 years; while the average amount of education acquired in US is 3.4 years and the average amount of education acquired abroad is over 9.5 years. The total years of 
potential experience is 20.5 years for this population; the average amount acquired in the US is 14.4 years while the average amount acquired abroad is 6.1 years. Approximately 44 percent of this population is female. Current English language ability, which is measured on a 5-point scale, is 3.5, which is between the two categories of "Very Well" and "Well".

When we restrict our sample to newly arrived immigrants in the US (after the year 2003), we find that they differ substantially from the larger sample. The new inflow of immigrants tends on average to be younger and have lower income than the entire stock of US immigrants on average. The mean of log annual earnings drops to 9.02 or about $\$ 19,100$ and the average age also decreases to 30.5 years old. This more restricted group have only about 12 years of education attained abroad. For these individuals, they have no US experience by assumption and therefore their total experience is only for the foreign country; this average is 12.4 years. Only 28 percent of this newly arrived immigrant group is female. The average value of current English language ability is slightly lower than the broader stock of US immigrants at 2.5; indicating that they, on average, are closer to speaking English "Not Well”.

III. Empirical Specification and Results for the American Community Survey Data

Our intention is to examine whether aggregated education and experience variables affect the inference in wage regressions for immigrant populations in the US. We separate out both the years of education as well as the labor market experience by home and host country. ${ }^{1}$ The simple wage regression that we run is the following:

\footnotetext{
${ }^{1}$ Our foreign experience variable includes any experience in the immigrant's home country or country other than the US.
} 
(1) Wages $=\alpha+\beta E d u+\gamma \operatorname{Exp}+X^{\prime} \theta+\varepsilon$

(2) Wages $=\alpha+\beta_{\text {Home }} E d u_{\text {Home }}+\beta_{U S} E d u_{U S}+\gamma_{\text {Home }} \operatorname{Exp}_{\text {Home }}+\gamma_{U S} \operatorname{Exp}_{U S}+X \theta+\varepsilon$

In equation 1 above, we regress the log of wages for each individual immigrant in the US on the aggregate measures of education and experience as would be available in standard crosssection data sets. The vector $\mathrm{X}$ contains a number of location characteristics such as the state or region of residence in the US and a home country fixed effect. Additionally, we include a measure of English language ability and the gender of the respondent. In equation 2 we separate out the education variable into a measure for the home country and one for education acquired in the US. Experience is decomposed in a similar manner.

We generated possible foreign education and US education in the following manner for the ACS data:

Foreign educ $=\left\{\begin{array}{cl}e d u c & \text { if agemig } \geq e d u c+6 \\ \text { agemig- } 6 & \text { if } 6<\text { agemig }<\text { educ } 6 \\ 0 & \text { if agemig } \leq 6\end{array}\right.$

$U S$ educ $=\left\{\begin{array}{c}e d u c \quad \text { if agemig }<6 \\ e d u c+6-\text { agemig if } 6 \leq \text { agemig }<\text { educ }+6 \\ 0 \quad \text { if agemig } \geq e d u c+6\end{array}\right.$

First we assigned total years of education for each immigrant according to the highest grade information contained in the ACS data. ${ }^{2}$ Then, we generated foreign education as total years of education if the age at migration is greater than the total years of education plus six years. Foreign education is age at migration minus six years if the individual migrated after age six but

\footnotetext{
${ }^{2}$ The ACS provides educational degrees and not actual years of education; therefore, we must assign years of education for education degrees. They are the following: for nursery 1 ; kindergarten $2 ; 1^{\text {st }}-4^{\text {th }}$ grade $3 ; 5^{\text {th }}-8^{\text {th }}$ grade 7 $9^{\text {th }}$ to $12^{\text {th }}$ grade 9 to 12 years; high school graduate 12 ; some college 13; associate degree 14; bachelor degree 16 ; masters degree 18; professional degree 20; doctorate degree 22 years.
} 
at an age that is less than his total education plus six years. Finally, the years of foreign education is set to zero when the age at migration is less than or equal to six years of age. In this case, we assume that the individual acquires all of his education in the host country.

To compute the US education, we assign the total education reported if the age of migration is greater than six years old. In the case when an individual migrates after age six but at an age that is less than his total education plus six years, we assign total US education as the total education amount plus six years and subtract out the age at migration. Finally, the total years of US education is assigned a value of zero if the age at migration is greater than the total years of education plus six years.

We create years of experience variable in the following manner:

Total $\exp =$ age - educ -6

Foreign $\exp =\left\{\begin{array}{c}\exp \text { if agemig } \leq \text { age-exp } \\ \text { age-agemig if agemig }>\text { age } \exp \\ 0 \text { otherwise }\end{array}\right.$

$U S \exp =\left\{\begin{array}{c}\text { agemig }-e d u c-6 \text { if agemig } \geq \text { age }-\exp \\ 0 \quad \text { if agemig }>\text { age }-\exp \end{array}\right.$

Total experience is taken as an immigrant's age minus his education and six years. Foreign experience is computed as total experience if the individual's age at migration is lower than his total age minus the experience. On the other hand if the age at migration is greater than the individual's total age less his experience, then we assign the foreign experience as his age less the age at migration. US experience is calculated as the age at migration minus the total years of education and six years if the age at migration is greater than or equal to the immigrant's total age less than his experience. Finally, we assign a value of zero if the age at migration is greater than the total age less than experience. 


\section{A. American Community Survey Results}

\section{i) Total Sample}

In Table 2 we provide the results from the wage regressions using the 2004 ACS data. This data set is representative of the US and therefore includes both legal and illegal immigrants. ${ }^{3}$ In the full sample, we find that the return to the years of education is positive and statistically significant at $9.8 \%$ in the first column and remains positive and significant when we disaggregate the variable into its US and foreign components. Column 3 also shows us that experience in the US is important in determining the immigrant's wage. We also find that the non-US experience also matters, although the coefficient is half the size of the US experience coefficient. Another significant finding is the size of the coefficients on the female and English language ability variables. English language ability plays a small and insignificant role here, whereas being a female has a larger negative effect on earnings.

\section{ii) New Arrivals}

In the ACS data it is not possible to perfectly distinguish where education was acquired and whether an individual had previous experience in the US and then subsequently left and returned to the US. Therefore, in an attempt to isolate the effect of foreign country education and experience, we restrict our analysis to newly arrived individuals (within the past year) who are not US citizens at the time of the survey. As is typical of the literature, we construct education and experience variables for the US using date of arrival; therefore by construction these individuals have no US experience or education. In column 7 we find that the return to

\footnotetext{
${ }^{3}$ For instance, prior to the 2000 US Census, the exact year of migration was not available - migration years were given in 3 year categories in 1990 census or 5 year categories in 1980 and 1970 census. While it is still the case that exact years of education in the home country are not available, any assumptions or inferences made about human capital acquired abroad have to be more accurate than when year of arrival was given in broad year categories.
} 
foreign education is $8.7 \%$. The return to foreign experience is positive and statistically significant at $2 \%$ which is very close to what we found in column 6 of panel A for US experience.

\section{iii) ACS Data Separated by Gender}

We run separate regressions on the women and then the men alone. This analysis is provided in Table 3. We find that women have a slightly higher estimated coefficient on both US and foreign years of education as compared to the men-only regressions. These differences are statistically significantly different from one another. This suggests that immigrant women have a higher return to education than men in the US. Additionally, this holds true for whether the education was acquired in the US or abroad.

The disaggregated experience variables show much less difference between the male and female subpopulations. The coefficient on US experience is positive at 0.023 for women and 0.028 for men and both are statistically significant. Foreign experience also appears to matter, but it is smaller for both men and women; the estimated coefficients are less than half that of the US experience coefficient. Finally, English language ability appears to bring a larger increase in wages for men than for women.

\section{New Immigrant Survey Data}

Our findings with the ACS indicate that in general we do not have to be very concerned about the aggregation of the years of education variable; it does not appear to be a problem whether we know where the individual acquired his educational attainment. The estimated 
coefficients on US and foreign educational attainment were not statistically significantly different from one another in our ACS regressions (column 3 of Table 2).

We now examine the validity of our assumptions that we used to define our education and experience variables in the ACS. In order to examine these assumptions, we turn to the New Immigrant Survey data. The New Immigrant Survey (NIS) is a representative sample of new legal permanent residents to the US who arrived between May and November in 2003. This data contains an extensive set of pre-migration modules that focus specifically on labor market experiences and educational attainment. The total sample consists of 8573 adults; however, we restrict our sample to working aged adults, 18-65, who are currently employed in the US. Finally, we omit the observations that are missing education, year of birth, year left the country of birth, and the top and bottom five percent of the earnings distribution. Our largest sample size contains 2203 observations. Table 4 details the sample selection procedure for our analysis that follows.

Table 5 provides the descriptive statistics for our NIS sample. The mean of log annual earnings is 9.86 , or about $\$ 19,000$. For this sample the average age is 36 years old; this may reflect that the sample is composed of new legal immigrants and does not include the illegal population. The total years of education is 13 years; the average amount of education acquired in the US is less than one year and the average amount of education acquired abroad is over 12 years. The total years of experience are 17 years for this population; the average amount acquired in the US is 7 years and the average amount acquired abroad is 11 years. Approximately 40 percent of this population is female. Current English language ability is 2.7 which fall between the two categories of "Not Well" and "Well" on this four point scale (with "Very Well" and "Not at all” being the two extreme categories). 


\section{A. NIS Variable Creation}

The NIS data contains information on the total number of years of education as well as the total years of education acquired in the US; this innovation allows researchers to more accurately assess the number of education acquired abroad. We created a variable that gave the total years of education abroad by subtracting the total years of US education from the total years of education.

The experience variable for the NIS data was computed in the following manner:

Foreign exp = Year Left Home country - Year born - Foreign Education - 6

US exp= $2004-$ Year Left- US educ

Total exp $=$ Foreign $\exp +U S \exp$

The experience variables were first calculated for the foreign and US experience in the NIS data. Foreign experience is simply the year the individual first left their home country minus their year of birth and years of education and six years. We do augment this experience variable for a few individuals who have reported a return trip to their home country or to another foreign country in the period after leaving their home country and prior to arrival in the US. The NIS data reports on other trips outside of the home country and prior to arriving in the US in 2003. We examine only the previous three trips - there are very few people who report more than three trips prior to their arrival in the US. We also augment the US experience variable. We have found that newly arrived legal migrants to the US also have had some US experience prior to this most recent move. Therefore, we have a highly accurate count of both US and foreign experience. 
B. New Immigrant Survey Results

i). Total Sample

Table 6 provides the results from the regressions described above. We show the simplest regression in column one with the aggregate education and experience variables. The coefficient on years of education is 0.03 and statistically significant at the $1 \%$ level. The coefficient on years of work experience is small at 0.008 but it is statistically significant at the $1 \%$ level as well. The other two variables indicate that being a female decreases log annual wages and that having better English language abilities increases wages. These regressions include the regional country of origin and US region of residence control variables.

In columns 2 and 3 of Table 6 we separate out the education and experience variables by where they were acquired. The results from column 2 indicate that the returns to education do not differ across the two types of education (the two coefficients are not statistically significantly different from one another); however, only the coefficient on foreign education is statistically significant from zero. The remaining coefficients do not change by very much.

Column 3 separates out work experience into two different variables. We find that the two coefficients on education increases in magnitude and remains statistically significant for foreign years of education. The coefficient on US years of work experience increases in size by a factor of five and is statistically significant at the $1 \%$ level. However, the foreign years of experience actually become negative, but it is not statistically significant.

Overall, the findings from these three regressions with the entire pooled sample suggest that aggregating years of education is not problematic in a standard wage regression for immigrants: the estimated coefficients across the two types of education do not differ statistically from one another. On the other hand, aggregating the work experience variable gives us an 
average coefficient that differs significantly from the disaggregated variables. In fact, using an aggregated years of experience variable substantially underestimates the return to US years of experience (the difference between 3.9 and $0.8 \%$ ).

\section{ii) New Arrivals}

Restricting our analysis to the new arrivals to the US - individuals who were previously living in a foreign country - we find that the results have some striking differences from earlier regression results in the ACS. Column 4 reports the results for these non-adjustee legal immigrants. The coefficient on total years of education is similar to what we found in column 1 . The return to employment experience for this group of new arrivals to the US is small and statistically insignificant. Females in this group face less of a decrease in their overall wages as compared to the larger pooled sample.

We separate out the source of the education by US and foreign locations in column 5 . Quite surprisingly, the coefficient on the years of education in the US jumps to $15.5 \%$ and is statistically significant. The coefficient on foreign education is still positive and statistically significant but it is comparatively very small at 0.025 . We were puzzled by this result and examined the kind of education a newly arriving immigrant had acquired in the US. The standard assumption is that new arrivals have zero years of US-acquired education. The data indicates that a number of these individuals actually received graduate degrees (many of them MBAs) in the US at some earlier date and then must have subsequently left the US only to return with green cards several years later. ${ }^{4}$ Therefore, these few individuals (41 people) are driving the relatively high return to years of US education. In column 7 we remove individuals who

\footnotetext{
${ }^{4}$ We have adjusted the data to include years spent in the US prior to the arrival in 2003. Given past migration histories contained in the NIS data we have found that 95 individuals out of the 2195 sample resided in the US and then subsequently left the US to return again in 2003. Our analysis has included these additional years in the US.
} 
have had previous education in the US. Column 6 separates out the source of work experience. The coefficient on US experience is positive and statistically significant; while the coefficient on home country labor market experience is not statistically significant. Additionally, it is important to note that the coefficient on foreign education is small and statistically insignificant in column 7. However, the coefficient on English language ability is positive and highly statistically significant indicating that foreign education may merely be a proxy for English language abilities in the US.

We also restrict our analysis to just the males and the females in separate regressions. A surprising finding is that there appears to be no difference in the size or the statistical significance on the foreign years of educational attainment between men and women; education acquired in the US appears to have no effect on log wages for either men or women in this sample. The coefficient is approximately 0.29 for women and 0.35 for men and both are statistically significant at the $5 \%$ level. These disaggregated measures of educational attainment do not differ drastically from the aggregate measures of education shown in columns 1 and 4 for women and men respectively; this is a general result that carries over from the pooled regressions. Experience in the US is an important determinant of log wages for both men and women and foreign experience does not appear to matter; this result is consistent with our pooled results reported earlier.

\section{Conclusion}

Our results indicate that aggregating education variables does not appear to be problematic for a pooled sample of immigrants either in the nationally representative sample of the entire immigrant stock in the US or for new legal immigrants to the US. There is some 
evidence, however, that the newly arrived legal immigrants may have some positive US education experience which is often assumed to be zero with standard data sets. The return to US education in these cases can be quite large, reflecting that some of the new immigrants have completed previous graduate or college degrees in the US. On the other hand the return to foreign education is not necessarily important when current English language abilities are included in a regression model. ${ }^{5}$

Disaggregating experience acquired in the US or abroad is actually a more important distinction. We find that the estimated coefficient from the total years of experience is small $0.8 \%$. However, when we disaggregate the variable, we find that the coefficient on US experience increases dramatically and is highly statistically significant, while foreign experience is not. In our ACS sample, we find that the experience variable is not affected as much by separating out these variables into US and foreign components.

In further work we intend to fully examine how these differences in human capital acquired abroad differs by the country of origin. We anticipate there to be significant differences across origin countries especially with regard to whether English language was spoken in the origin.

\footnotetext{
${ }^{5}$ In results not reported, we ran the same regressions without the English language ability and found that the estimated coefficients on both US and foreign education increase in size and statistical significance.
} 


\section{Reference:}

Aslan Zorlu \& Joop Hartog, 2009. “How important is homeland education for refugees’ economic position in The Netherlands?”, Journal of Population Economics, 22 (1).

Bernt Bratsberg \& James F. Ragan , 2002." The impact of host-country schooling on earnings: a study of male immigrants in the United States," Journal of Human Resources, vol. 37(1), pages 63-105.

Friedberg, Rachel M, 2000."You Can't Take It with You? Immigrant Assimilation and the Portability of Human Capital," Journal of Labor Economics, University of Chicago Press, vol. 18(2), pages 221-51, April.

Joseph Schaafsma \& Arthur Sweetman, 2001. "Immigrant earnings: age at immigration matters," Canadian Journal of Economics, Canadian Economics Association, vol. 34(4), pages 1066-1099, November.

Robert F. Schoeni, 1997. "New Evidence on the Economic Progress of Foreign-Born Men in the 1970s and 1980s”, Journal of Human Resources, 32(4). 
Table 1: Immigrant Characteristics for the American Community Survey Data

\begin{tabular}{|c|c|c|c|c|}
\hline & \multicolumn{2}{|c|}{ Total Sample } & \multicolumn{2}{|c|}{$\begin{array}{c}\text { Newly Arrived } \\
\text { Immigrants (After 2003) }\end{array}$} \\
\hline & Mean & Std. & Mean & Std. \\
\hline Mean of Log Annual Earnings & 10.099 & $(1.033)$ & 10.099 & $(1.033)$ \\
\hline Age & 39.578 & (11.537) & 39.578 & (11.537) \\
\hline Total Years of Education & 12.979 & (4.097) & 12.979 & (4.097) \\
\hline Years of Education in the US & 3.395 & $(5.415)$ & 3.395 & $(5.415)$ \\
\hline Years of Education Abroad & 9.584 & $(5.922)$ & 9.584 & $(5.922)$ \\
\hline Total Years of Experience & 20.599 & $(12.070)$ & 20.599 & $(12.070)$ \\
\hline Years of Experience in the US & 14.419 & $(10.408)$ & 14.419 & $(10.408)$ \\
\hline Years of Experience Abroad & 6.180 & $(8.332)$ & 6.180 & $(8.332)$ \\
\hline Female Indicator & 0.446 & $(0.497)$ & 0.446 & $(0.497)$ \\
\hline Ability to Speak English & 3.498 & $(1.179)$ & 3.498 & $(1.179)$ \\
\hline
\end{tabular}

Notes: Immigrants who have wage and salary income in 2004 ACS data is used. Female is in percentage. " New immigrant" indicates immigrants who migrate to US after 2002. 
Table 2: OLS Wage Regression using the American Community Survey Data for Immigrant Population

\begin{tabular}{|c|c|c|c|c|c|c|c|}
\hline & \multicolumn{3}{|c|}{ Total Sample } & \multicolumn{3}{|c|}{ Non-US Citizens } & \multirow{2}{*}{$\begin{array}{c}\text { Newly Arrived } \\
\text { Immigrants } \\
\text { (After 2003) }\end{array}$} \\
\hline & $(1)$ & $(2)$ & (3) & (4) & $(5)$ & (6) & \\
\hline \multirow[t]{2}{*}{ Total Years of Education } & 0.098 & & & 0.079 & & & \\
\hline & $(0.015)$ & & & $(0.015)$ & & & \\
\hline \multirow{3}{*}{ Education in the US } & & & & & & & \\
\hline & & 0.101 & 0.094 & & 0.066 & 0.059 & \\
\hline & & $(0.015)$ & $(0.015)$ & & $(0.015)$ & $(0.015)$ & \\
\hline \multirow{2}{*}{ Education Foreign } & & 0.098 & 0095 & & 0079 & 0077 & 0087 \\
\hline & & $\begin{array}{c}0.098 \\
(0.015)\end{array}$ & $\begin{array}{c}0.095 \\
(0.015)\end{array}$ & & $\begin{array}{c}0.079 \\
(0.015)\end{array}$ & $\begin{array}{c}0.077 \\
(0.015)\end{array}$ & $\begin{array}{c}0.087 \\
(0.029)\end{array}$ \\
\hline \multirow{2}{*}{ Total Employment Experience } & 0.021 & 0.022 & & 0.021 & 0.020 & & \\
\hline & $(0.001)$ & $(0.001)$ & & $(0.001)$ & $(0.001)$ & & \\
\hline \multirow{3}{*}{ Employment Experience - US } & & & & & & & \\
\hline & & & 0.025 & & & 0.027 & \\
\hline & & & $(0.001)$ & & & $(0.002)$ & \\
\hline \multicolumn{2}{|c|}{ Employment Experience - Non-US } & & 0438 & & 0466 & 0012 & 0020 \\
\hline & US & & $\begin{array}{l}-0.438 \\
(0.036)\end{array}$ & & $\begin{array}{l}-0.466 \\
(0.031)\end{array}$ & $\begin{array}{c}0.012 \\
(0.002)\end{array}$ & $\begin{array}{c}0.020 \\
(0.007)\end{array}$ \\
\hline \multirow{2}{*}{ Female } & -0.435 & -0.436 & -0.438 & -0.470 & -0.466 & -0.468 & -0.315 \\
\hline & $(0.036)$ & $(0.036)$ & $(0.036)$ & $(0.032)$ & $(0.031)$ & $(0.031)$ & $(0.117)$ \\
\hline \multirow[t]{2}{*}{ English Language Ability } & 0.105 & 0.099 & 0.077 & 0.100 & 0.111 & 0.089 & 0.149 \\
\hline & $(0.012)$ & $(0.011)$ & $(0.010)$ & $(0.011)$ & $(0.011)$ & $(0.009)$ & $(0.072)$ \\
\hline \multirow{2}{*}{ Constant } & 8.467 & 8.468 & 8.590 & 8.705 & 8.722 & 8.808 & 6.693 \\
\hline & $(0.243)$ & $(0.244)$ & $(0.239)$ & $(0.254)$ & $(0.244)$ & $(0.247)$ & $(0.533)$ \\
\hline State of Residence Controls & $\mathrm{Y}$ & $\mathrm{Y}$ & $\mathrm{Y}$ & $\mathrm{Y}$ & $\mathrm{Y}$ & $\mathrm{Y}$ & $\mathrm{Y}$ \\
\hline Country of Birth Controls & $\mathrm{Y}$ & $\mathrm{Y}$ & $\mathrm{Y}$ & Y & $\mathrm{Y}$ & $\mathrm{Y}$ & $\mathrm{Y}$ \\
\hline Observations & 55879 & 55879 & 55879 & 27597 & 27597 & 27597 & 531 \\
\hline R-Squared & 0.248 & 0.248 & 0.248 & 0.232 & 0.2334 & 0.2412 & 0.281 \\
\hline & & & & & & & \\
\hline & & & & & & & \\
\hline
\end{tabular}


Table 3: OLS Wage Regression using the American Community Survey Data for Immigrant Population by Gender

\begin{tabular}{|c|c|c|c|c|c|c|}
\hline & \multicolumn{3}{|c|}{ Females } & \multicolumn{3}{|c|}{ Males } \\
\hline & (1) & $(2)$ & (3) & (4) & $(5)$ & (6) \\
\hline \multirow[t]{2}{*}{ Total Years of Education } & 0.103 & & & 0.094 & & \\
\hline & $(0.011)$ & & & $(0.016)$ & & \\
\hline \multirow[b]{2}{*}{ Education in the US } & & 0111 & 0.105 & & 0003 & $0 \Omega 84$ \\
\hline & & $\frac{0.111}{(0010)}$ & $\frac{0.105}{(0010)}$ & & $\frac{0.093}{(0017)}$ & $\frac{0.084}{(0.018)}$ \\
\hline & & & & & & \\
\hline \multirow[t]{2}{*}{ Education Foreign } & & 0.103 & 0.099 & & 0.094 & 0.091 \\
\hline & & $(0.011)$ & $(0.012)$ & & $(0.017)$ & $(0.017)$ \\
\hline \multirow[t]{2}{*}{ Total Employment Experience } & 0.019 & 0.020 & & 0.023 & 0.023 & \\
\hline & $(0.001)$ & $(0.001)$ & & $(0.001)$ & $(0.001)$ & \\
\hline \multirow{3}{*}{ Employment Experience - US } & & & & & & \\
\hline & & & 0.023 & & & 0.028 \\
\hline & & & $(0.001)$ & & & $(0.001)$ \\
\hline \multirow[t]{2}{*}{ Employment Experience - Non-US } & & & 0.012 & & & 0.012 \\
\hline & & & $(0.002)$ & & & $(0.002)$ \\
\hline & & & & & & \\
\hline \multirow[t]{2}{*}{ English Language Ability } & 0.106 & 0.088 & 0.069 & 0.105 & 0.107 & 0.081 \\
\hline & $(0.016)$ & $(0.016)$ & $(0.016)$ & $(0.011)$ & $(0.011)$ & $(0.009)$ \\
\hline \multirow[t]{2}{*}{ Constant } & 7.612 & 7.611 & 7.725 & 8.005 & 8.005 & 8.136 \\
\hline & $(0.159)$ & $(0.160)$ & $(0.153)$ & $(0.242)$ & $(0.243)$ & $(0.244)$ \\
\hline State of Residence Controls & $\mathrm{Y}$ & $\mathrm{Y}$ & $\mathrm{Y}$ & $\mathrm{Y}$ & $\mathrm{Y}$ & $\mathrm{Y}$ \\
\hline Country of Birth Controls & $\mathrm{Y}$ & $\mathrm{Y}$ & $\mathrm{Y}$ & $\mathrm{Y}$ & $\mathrm{Y}$ & $\mathrm{Y}$ \\
\hline Observations & 24896 & 24896 & 24896 & 30983 & 30983 & 30983 \\
\hline R-Squared & 0.195 & 0.197 & 0.201 & 0.2659 & 0.266 & 0.2745 \\
\hline & & & & & & \\
\hline & & & & & & \\
\hline
\end{tabular}




\begin{tabular}{|l|c|}
\hline \hline & 8533 \\
\hline Total Sample & 8503 \\
\hline Not Missing Total Years of Education & 8255 \\
\hline Not Missing US Education & 7651 \\
\hline Restricting Sample to individuals aged 18-65 & 7373 \\
\hline Not Missing Year Left Home Country & 6933 \\
\hline Not Missing Year Born & 2887 \\
\hline Dropping Individuals with no reported Annual Wage or Salary Information & 2599 \\
\hline Dropping the top and bottom 5\% of the Annual Wage and Salary Distribution & 2203 \\
\hline Omitting those observations with missing information on other covariates & $\mathbf{2 2 0 3}$ \\
\hline \hline
\end{tabular}

Table 5: Immigrant Characteristics for the New Immigrant Survey

\begin{tabular}{|lccc|}
\hline \hline & & & \\
\cline { 2 - 2 } Mean of Log Annual Earnings & Mean & & Std. \\
\cline { 2 - 2 } Age & 9.886 & & $(0.953)$ \\
\hline Total Years of Education & 36.378 & & $(9.257)$ \\
\hline Years of Education in the US & 13.202 & & $(4.408)$ \\
\hline Years of Education Abroad & 0.742 & & $(1.927)$ \\
\hline Total Years of Experience & 12.461 & & $(4.422)$ \\
\hline Years of Experience in the US & 17.810 & & $(10.476)$ \\
\hline Years of Experience Abroad & 6.810 & & $(6.297)$ \\
\hline Female Indicator & 11.000 & & $(9.459)$ \\
\hline Ability to Speak English & 0.413 & & $(0.492)$ \\
\hline \hline
\end{tabular}

Notes: Sample size is 2,203. 
Table 6: OLS Wage Regression for New Legal Permanent Residents using the New Immigrant Survey

\begin{tabular}{|c|c|c|c|c|c|c|c|}
\hline & \multicolumn{3}{|c|}{ Pooled Sample } & \multicolumn{3}{|c|}{ Non-Adjustee Sample Only } & \multirow{2}{*}{$\begin{array}{c}\begin{array}{c}\text { Non-Adjustee } \\
\text { Sample without } \\
\text { previous US } \\
\text { education }\end{array} \\
(7)\end{array}$} \\
\hline & (1) & $(2)$ & (3) & $(4)$ & $(5)$ & $(6)$ & \\
\hline \multirow[t]{2}{*}{ Total Years of Education } & 0.030 & & & 0.031 & & & \\
\hline & $(0.007)$ & & & $(0.011)$ & & & \\
\hline \multirow[t]{2}{*}{ Education in the US } & & 0.018 & 0.030 & & 0.155 & 0.132 & \\
\hline & & $(0.026)$ & $(0.022)$ & & $(0.032)$ & $(0.036)$ & \\
\hline \multirow[t]{2}{*}{ Education Foreign } & & 0.030 & 0.032 & & 0.025 & 0.024 & 0.024 \\
\hline & & & $(0.006)$ & & $(0.012)$ & $(0.013)$ & $(0.017)$ \\
\hline \multirow[t]{2}{*}{ Total Employment Experience } & 0.008 & 0.007 & & 0.001 & 0.000 & & \\
\hline & $(0.004)$ & $(0.004)$ & & $(0.006)$ & $(0.006)$ & & \\
\hline \multirow[t]{2}{*}{ Employment Experience - US } & & & 0.039 & & & 0.026 & 0.030 \\
\hline & & & $(0.005)$ & & & $(0.007)$ & $(0.007)$ \\
\hline \multicolumn{2}{|l|}{ Employment Experience - Non-US } & & -0.003 & & & -0.004 & -0.005 \\
\hline & & & $(0.004)$ & & & $(0.006)$ & $(0.007)$ \\
\hline \multirow[t]{2}{*}{ Female } & -0.281 & -0.280 & -0.277 & -0.134 & -0.138 & -0.161 & -0.164 \\
\hline & $(0.088)$ & $(0.004)$ & $(0.081)$ & $(0.148)$ & $(0.148)$ & $(0.140)$ & $(0.135)$ \\
\hline \multirow[t]{2}{*}{ English Language Ability } & 0.293 & 0.302 & 0.225 & 0.349 & 0.323 & 0.277 & 0.271 \\
\hline & $(0.044)$ & $(0.038)$ & $(0.029)$ & $(0.053)$ & $(0.057)$ & $(0.055)$ & $(0.063)$ \\
\hline \multirow[t]{2}{*}{ Constant } & 9.509 & 9.467 & 9.574 & 9.654 & 9.447 & 9.609 & 8.752 \\
\hline & $(0.276)$ & $(0.233)$ & $(0.188)$ & $(0.288)$ & $(0.280)$ & $(0.292)$ & $(0.499)$ \\
\hline State of Residence Controls & $\mathrm{Y}$ & Y & $\mathrm{Y}$ & $\mathrm{Y}$ & $\mathrm{Y}$ & $\mathrm{Y}$ & $\mathrm{Y}$ \\
\hline Country of Birth Controls & $\mathrm{Y}$ & $\mathrm{Y}$ & $\mathrm{Y}$ & $\mathrm{Y}$ & $\mathrm{Y}$ & $\mathrm{Y}$ & $\mathrm{Y}$ \\
\hline Observations & 2,195 & 2,195 & 2,195 & 737 & 737 & 737 & 696 \\
\hline R-Squared & 0.294 & 0.295 & 0.335 & 0.295 & 0.302 & 0.313 & 0.290 \\
\hline \multicolumn{8}{|c|}{ Notes: } \\
\hline & & & & & & & \\
\hline
\end{tabular}


Table 7: OLS Wage Regression for New Legal Permanent Residents using the New Immigrant Survey Data by Gender

\begin{tabular}{|c|c|c|c|c|c|c|c|c|}
\hline & \multicolumn{3}{|c|}{ Females } & \multicolumn{3}{|c|}{ Males } & \multirow{2}{*}{$\frac{\text { Employment }}{(7)}$} & \multirow{2}{*}{$\frac{\text { Family }}{(8)}$} \\
\hline & $(1)$ & $F \quad(2)$ & (3) & $(4)$ & (5) & (6) & & \\
\hline \multirow[t]{2}{*}{ Total Years of Education } & 0.028 & & & 0.032 & & & & \\
\hline & $(0.008)$ & & & $(0.007)$ & & & & \\
\hline & & & & & & & & \\
\hline \multirow[t]{2}{*}{ Education in the US } & & 0.030 & 0.037 & & 0.011 & 0.027 & -0.005 & 0.008 \\
\hline & & $(0.033)$ & $(0.031)$ & & $(0.025)$ & $(0.020)$ & $(0.023)$ & $(0.024)$ \\
\hline \multirow{2}{*}{ Education Foreign } & & 0028 & 0029 & & 0033 & 0035 & 0022 & 0013 \\
\hline & & $\begin{array}{c}0.028 \\
(0.008)\end{array}$ & $\begin{array}{c}0.029 \\
(0.008)\end{array}$ & & $\begin{array}{c}0.053 \\
(0.006)\end{array}$ & $\frac{0.053}{(0.005)}$ & $\begin{array}{c}0.0 \angle 2 \\
(0.017)\end{array}$ & $\begin{array}{c}0.013 \\
(0.008)\end{array}$ \\
\hline \multirow{3}{*}{ Total Employment Experienc } & & & & & & & & \\
\hline & 0.008 & 0.008 & & 0.008 & 0.008 & & & \\
\hline & $(0.003)$ & $(0.004)$ & & $(0.005)$ & $(0.005)$ & & & \\
\hline \multicolumn{2}{|l|}{ Employment Experience - US } & & 0.029 & & & 0.040 & $(0.014)$ & 0.025 \\
\hline & & & $(0.005)$ & & & $(0.006)$ & $(0.010)$ & $(0.004)$ \\
\hline \multicolumn{2}{|c|}{ Employment Experience - Non-US } & & 0000 & & & 0003 & 0007 & $=0002$ \\
\hline 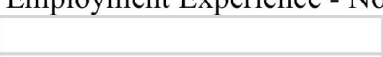 & 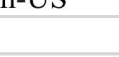 & & $(0.004)$ & & & $(0.005)$ & $(0.007)$ & $(0.003)$ \\
\hline & & & & & & & & \\
\hline \multirow[t]{2}{*}{ Female } & & & & & & & -0.308 & -0.267 \\
\hline & & & & & & & $(0.185)$ & $(0.058)$ \\
\hline \multirow{2}{*}{ English Language Ability } & 0.293 & 0.292 & 0.242 & 0.280 & 0.296 & 0.198 & 0.269 & 0.160 \\
\hline & $(0.051)$ & $(0.047)$ & $(0.038)$ & $(0.050)$ & $(0.044)$ & $(0.039)$ & $(0.056)$ & $(0.064)$ \\
\hline \multirow[t]{2}{*}{ Constant } & 8.638 & 8.639 & 8.818 & 9.464 & 9.399 & 9.663 & 9.545 & 9.755 \\
\hline & $(0.415)$ & $(0.411)$ & $(0.345)$ & $(0.293)$ & $(0.257)$ & $(0.215)$ & $(0.322)$ & $(0.538)$ \\
\hline State of Residence Controls & $\mathrm{Y}$ & $\mathrm{Y}$ & $\mathrm{Y}$ & $\mathrm{Y}$ & $\mathrm{Y}$ & $\mathrm{Y}$ & $\mathrm{Y}$ & $\mathrm{Y}$ \\
\hline Country of Birth Controls & $\mathrm{Y}$ & $\mathrm{Y}$ & $\mathrm{Y}$ & $\mathrm{Y}$ & $\mathrm{Y}$ & $\mathrm{Y}$ & $\mathrm{Y}$ & $\mathrm{Y}$ \\
\hline Observations & 910 & 910 & 910 & 1293 & 1293 & 1293 & 581 & 628 \\
\hline R-Squared & 0.272 & 0.272 & 0.298 & 0.3353 & 0.337 & 0.3817 & 0.317 & 0.232 \\
\hline & & & & & & & & \\
\hline & & & & & & & & \\
\hline
\end{tabular}

